\title{
STRENGTH OF STRUCTURAL FINGER-JOINTS REINFORCED WITH FIBERS
}

\author{
Cleide Beatriz Bourscheid ${ }^{1 *}$, Rodrigo Figueiredo Terezo ${ }^{2}$, Polliana d'Angelo Rios ${ }^{2}$, Alexsandro Bayestorff da
} Cunha $^{2}$, Deyvis Borges Waltrick ${ }^{2}$, João Laryan Borges Righez ${ }^{2}$

\author{
1*Université Laval, Québec, Québec, Canadá, bourscheidcleide@ gmail.com \\ 2Universidade do Estado de Santa Catarina, Lages, Santa Catarina, Brasil, rodrigo.terezo@udesc.br, polliana.rios@udesc.br, \\ alexsandro.cunha@udesc.br, eng.borges@outlook.com,joaolaryanbr@gmail.com
}

Received for publication: 28/06/2017 - Accepted for publication: 26/09/2018

\begin{abstract}
The finger-joints are the kind of top joints most used in wood blades to manufacture glued laminated timber (GLULAM) and present direct influence on their rigidity and final mechanical strength. Thus, the objective of this study was to evaluate the tensile strength parallel to grain with different compositions of reinforcements concentrated on finger-joints. Two geometries were used to execute the finger-joints and two species: Pinus taeda and Eucalyptus spp. The reinforcements were fabrics from glass or carbon fibers bonded with polyurethane structural adhesive. The treatments used were: "A-Glass", "A-Glass2", "A-Carbon", "A-Without reinforcement", "B-Glass", "B-Glass2", "B-Carbon" and "B-Without reinforcement", being "A" or "B", the geometries and "2", the number of layers of tissue. For statistical analysis, the Dunnett test was used at $95 \%$ confidence interval. The results showed that the execution of the unreinforced finger-joints decreased the tensile strength of the woods. For P. taeda, all the treatments were significantly inferior to the control (without finger-joints), and for Eucalyptus spp., only the treatment "A-Unreinforced" presented inferior performance to the control (without finger-joints), all others presented equivalent mechanical resistance to solid wood. It can be concluded that for the Eucalyptus spp. wood, the application of reinforcement on the structural finger-joints improves the tensile strength, equating to the solid wood.

Keywords: finger-joint, geometry; composites; tensile strength, forest planted wood.
\end{abstract}

\begin{abstract}
Resumo
Resistência de emendas por entalhes múltiplos reforçadas com fibras. As emendas por entalhes múltiplos são a união de topo entre lâminas de madeira mais utilizadas na fabricação da Madeira Laminada Colada (MLC) e exercem influência direta na sua rigidez e resistência mecânica final. Desta forma, o objetivo deste estudo foi avaliar a resistência à tração paralela às fibras da madeira com diferentes composições de reforços sobre as emendas. Foram utilizadas duas geometrias para execução dos entalhes múltiplos e duas espécies: Pinus taeda e Eucalyptus spp.. Os reforços foram tecidos de fibras de vidro ou de carbono colados com adesivo estrutural poliuretano reativo. Os tratamentos empregados foram: "A-Vidro", "A-Vidro2", "A-Carbono", "ASem reforço", "B-Vidro", "B-Vidro2", "B-Carbono" "B-Sem reforço", sendo "A" ou "B", as geometrias e "2", o número de camadas do tecido. Para análise estatística utilizou-se o teste de Dunnett a 95\% de confiabilidade. Os resultados mostraram que a execução das emendas sem aplicação de reforço diminuíram a resistência à tração paralela das madeiras. Para o $P$. taeda, todo os tratamentos foram significativamente inferiores à testemunha (sem emendas), e para o Eucalyptus spp., apenas o tratamento "A-Sem reforço" apresentou desempenho inferior à testemunha sem emendas, todos os demais apresentaram resistência mecânica equivalente à madeira maciça. Pode-se concluir que para a madeira de Eucalyptus spp. a aplicação de reforço sob as emendas melhora a resistência à tração paralela, equiparando-se à madeira maciça.

Palavras-chave: uniões dentadas; geometria; compósitos; resistência à tração; madeira de floresta plantada.
\end{abstract}

\section{INTRODUCTION}

Composites industry technologies have been used frequently by engineering. The use of new synthetic materials, in conjunction with natural polymers, makes industrial products meet the desired properties in project and performance standards. Wood and its derivatives are among the most important building materials and have become more and more usual. However, the availability of large bulk parts is becoming rare and costly, even when coming from certified homogenous plantations. Moreover, the massive parts possess modified physical and mechanical characteristics due to presence of knots, splits and cracks. These defects have detrimental effect in the tensile and compressive strengths (KHELIFA et al., 2015b).

For Segundinho et al. (2013), Glued Laminated Timber (GLULAM) presents advantages in relation to solid wood, not only for preferential usage of planted forest species (Pinus taeda and Eucalyptus spp.), but in function of an industrial process that aims to diminish the influence of defects by means of classification, lamination and gluing. The top connection between wood blades can be performed through glued multiple longitudinal slots (finger-joints) or bevels. You can also remove the defects of the sheets and unite them again 
through these processes. Therefore, accuracy is essential in the execution to achieve the quality standards requirements (MOLINA et al., 2016).

Finger-joints are the most suitable for GLULAM according to their structural features such as: linearity, dimensional stability, resistance loss prediction and gluing largest area (KHELIFA et al., 2015a). The used geometries are conducted by standards, as European EN 385 (2001), that considers a 20mm $\left(\mathrm{L}_{\mathrm{d}}\right)$ length, base width $\left(t_{d}\right)$ of $6,2 \mathrm{~mm}$, top width $\left(b_{d}\right)$ of $1 \mathrm{~mm}$ and percentage of weakening $\left(\mathrm{v}_{\mathrm{d}}\right)$ up to $16 \%$. In Brazil, there is the revision project of the Brazilian Standard PNBR 7190 (2011), that considers finger-joint geometries for structural purposes as: $\mathrm{L}_{d}=21 \mathrm{~mm}, \mathrm{t}_{\mathrm{d}}=7 \mathrm{~mm}, \mathrm{~b}_{\mathrm{d}}=1 \mathrm{~mm}$ and $\mathrm{v}_{\mathrm{d}} \leq 14 \%$, up to $\mathrm{L}_{\mathrm{d}}=28 \mathrm{~mm}, \mathrm{t}_{\mathrm{d}}=7 \mathrm{~mm}, \mathrm{~b}_{\mathrm{d}}=1$ $\mathrm{mm}$ and $\mathrm{v}_{\mathrm{d}} \leq 12 \%$.

Generally, wooden beams are more requested by parallel to the grain stresses and, consequently, to the GLULAM blades and its joints. Therefore, develop a new technology that is capable to resist tensile stress has been the objective of many researches in multiple longitudinal joints in recent years (BUSTOS et al., 2003; BAYATKASHKOLI et al., 2012; RAO et al., 2012; IWAKIRI et al., 2013; FINK \& KOHLER, 2015; KHELIFA et al., 2015a; HABIPI et al., 2016; KHELIFA et al., 2016). However, there are few works related to composite application exclusively in finger-joints (KHELIFA et al., 2015b).

Composites formed by fibers associated with a polymer matrix have been used to reinforce or to increase the final mechanical resistance and the modulus of elasticity $\left(\mathrm{E}_{\mathrm{W}}\right)$ of wooden structural elements. The fibers commonly used in this type of reinforcement are glass or carbon, associated to matrices which can be thermoplastic or thermosetting, depending on the application mode and use of the structure. In the reinforcement composites associated to wood, the most used matrices have been polyurethane, phenolic and epoxy (STERLEY et al. 2014).

In this sense, the objective of this research was to evaluate the performance of two geometries of fingerjoints for structural purposes in wood of Pinus taeda and Eucalyptus spp., with reinforcements of glass and carbon fibers fabrics glued with reactive polyurethane.

\section{MATERIALS AND METHOD}

Samples of the species were selected randomly in lots of commercial sawn wood with approximately $1 \mathrm{~m}^{3}$ each. Used wood came from different regions and suppliers, resulting in different processes in primary processing and drying phase. The wood of $P$. taeda used was provenient from planted forests of Santa Catarina State plateaus, with approach age of 28 years. In private sector company, logs were processed in 55 planks, with $300 \mathrm{~cm} \times 20 \mathrm{~cm} \times 2.2 \mathrm{~cm}$ of dimension, being conditionated outdoors by the period of 40 days until they obtained average humidity tenor about $18 \%$. Later, these planks were transfered and stored in covered area for 120 days in the Wood Technology Laboratoty, reaching an humidity tenor of $15.9 \%$.

The wood Eucalyptus spp. was provenient of planted forests in the region of Vale do Caí in the state of Rio Grande do Sul, Brazil, with age among 13 and 15 years old. The logs were selected randomly and sawn in 80 planks with $300 \mathrm{~cm} \times 20 \mathrm{~cm} \times 3 \mathrm{~cm}$ of dimension. The planks were primarily stored outdoor for approximatedly 30 day in order to lose water. Later, all pieces of Eucalyptus spp. Were kiln dried with temperature at $56^{\circ} \mathrm{C}$ and average humidity of $50 \%$ for 6 days, reaching mean moisture content of $12.3 \%$. Then, they were transfered and stored at the Wood Technology Laboratory.

\section{Manufacture of Test Specimens}

The planks of $P$. taeda had been resawn in 100 clear pieces, with dimensions of $60 \mathrm{~cm} \times 5 \mathrm{~cm} \times 2,2 \mathrm{~cm}$, and the wood of Eucalyptus spp. were sawed in 150 clear pieces, with dimensions of $60 \mathrm{~cm} \times 3 \mathrm{~cm}$, being removed $30 \mathrm{~cm}$ each end point. The difference of thickness between the species occurred due to the material being sourced from lumber industries and there was no overthickness compensation for wood retraction after drying. Figure 1 illustrates the steps for preparation of test specimens.

All the above samples were sawn in half, top cutted and milled in high rotation finger-joint machine with the geometries (A) acquired by the Wood Technology Laboratory and (B) used by industry (Figure 1b), as presented in the table 1 . All the samples were glued in up to 24 hours after the milling process.

The adhesive used was a monocomponent reactive polyurethane (PUR), characterized by mean grammage $1.15 \mathrm{~g} . \mathrm{cm}^{-3}$, mean solids content of $99.5 \%$ and mean viscosity $10,500 \mathrm{mPa} . \mathrm{s}$ at $20^{\circ} \mathrm{C}$. The grammage control of PUR adhesive was performed with aid of digital scale, in which the container was weighed before and after each glue application, achieving $200 \mathrm{~g} / \mathrm{m}^{2}$, as recommended of the manufacturer.

The gluing process of finger-joints (Figure 1C) was performed with two different processes: (A) with automatized hydraulical press in manufacter yard; e (B) with manual press in the Laboratory, monitored with automatic system of data acquisition, model MX440A® of HBM®, softwares Catman Easy® and Quantum X®, 
with load cell $\mathrm{U} 10 \mathrm{M}{ }^{\circledR}$ with $125 \mathrm{kN}$ capacity. The use of these two systems occured due to equipment availability in the 24 hours after samples milling.

Figure 1. Phases of the samples production.

Figura 1. Fases de produção de amostras.

(a)

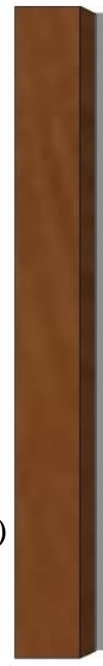

(b)

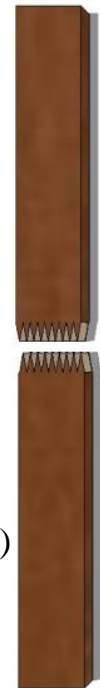

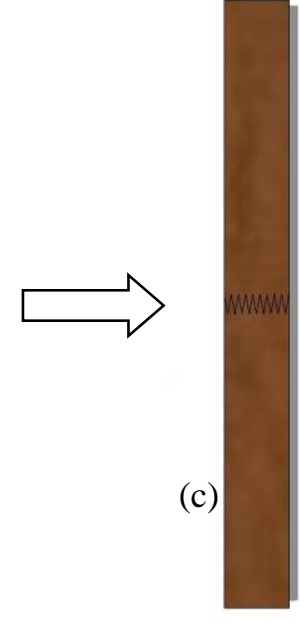
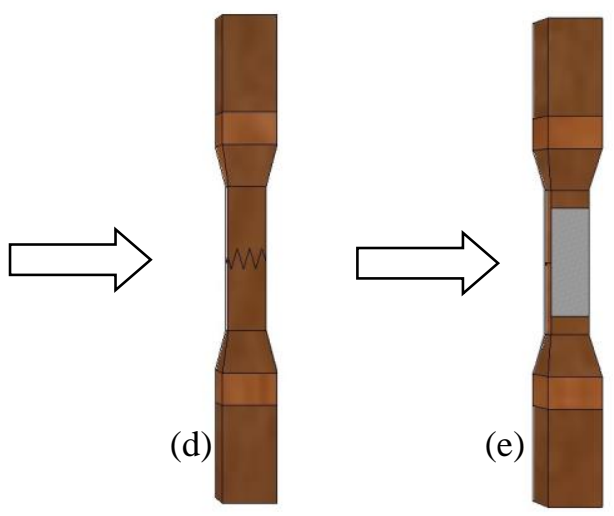

Caption: (a) Pieces with dimensions of $60 \mathrm{~cm}$ x $5 \mathrm{~cm}$ x 2,2 cm for P. taeda and of $60 \mathrm{~cm} \times 5 \mathrm{~cm} \times 3 \mathrm{~cm}$ for Eucalyptus spp.; (b) Pieces after milling; (c) Pieces after finger-joints gluing;(d) Test specimen drilled according to NBR 7190 (1997) and identification of density test specimen; (e) Finished test specimen, with the fiber fabrics glued on the finger-joints.

Table 1. Geometric variables according to used species and geometries.

Tabela 1. Variáveis geométricas de acordo com espécies e geometrias usada.

\begin{tabular}{lcccc}
\hline \multicolumn{1}{c}{ Treatments } & $\begin{array}{c}\text { Length } \\
L_{d}(\mathrm{~mm})\end{array}$ & $\begin{array}{c}\text { Width of base } t_{d} \\
(\mathrm{~mm})\end{array}$ & Tip width $b_{d}(\mathrm{~mm})$ & $\begin{array}{c}\text { Weakening Percentage } \\
v_{d}(\%)\end{array}$ \\
\hline P. taeda $-\mathrm{A}$ & 21,8 & 6,7 & 1,5 & $22 \%$ \\
P. taeda $-\mathrm{B}$ & 19,1 & 6,5 & 1,7 & $26 \%$ \\
Eucalyptus spp. - A & 20,5 & 6,5 & 1,5 & $23 \%$ \\
Eucalyptus spp. - B & 18,6 & 6,6 & 1,8 & $27 \%$ \\
\hline
\end{tabular}

Legend: A = geometry of the wood technology laboratory; B = usual geometry in GLULAM industry.

The gluing pressure in the industrial hydraulic system was 4.4 MPa for P. taeda and $8.8 \mathrm{MPa}$ for Eucalyptus spp. In the manual system of the Laboratory, the gluing pressure was $4.6 \mathrm{MPa}$ for P. taeda and 6.5 MPa for Eucalyptus spp. These values are lower than those recommended by PNBR 7190 (2011), because in preliminary tests there was a premature rupture of the finger-joints when the pressures suggested by the standard draft were used. The samples were stored for $72 \mathrm{~h}$ to completely dry the adhesive. After this period, all the samples were planed and sawed obtaining final dimensions of $45.0 \mathrm{~cm} \times 4.9 \mathrm{~cm} \times 1.8 \mathrm{~cm}$ and finally usinated (Figure 1D) according to the NBR 7190 (1997) tensile strength parallel to the grain specimen test.

\section{Reinforcement Application}

The synthetic fiber fabrics used as reinforcement were: (i) the bi-directional glass fiber fabric, screen type $1 \times 1$, with $5 \times 5$ yarns $/ \mathrm{cm}$, grammage of $200 \mathrm{gm}^{-2}$ and $0.18 \mathrm{~mm}$ thickness; and (ii) the bi-directional carbon fiber fabric, twill type $2 \times 2$, with $5 \times 5$ yarns $/ \mathrm{cm}$, grammage of $200 \mathrm{gm}^{-2}$ and $0.40 \mathrm{~mm}$ thickness.

In the central area of the test specimen of tensile strength parallel to the grains, the adhesive (PUR) was applied with the same control and gluing grammage of the finger-joints, the reinforcement fiber was positioned on this layer of adhesive, the deaeration was performed with the aid of a metal bar and finally a last layer of adhesive was applied. In the case of the treatments with double layer of reinforcement, the steps of fiber application, glue and deaeration were repeated. These processes were performed on both faces of the test specimen. All of them were superficially pressed with $1 \mathrm{MPa}$ of pressure, which is also controlled by the HBM® data acquisition system. The application of the reinforcements occurred up to 24 hours after the machining of the 
test specimens, following the same production recommendations of elements in GLULAM. An illustration of the finished test specimen can be seen in Figure 1e.

The length of the applied fiber in the region of the finger-joint was in the ratio of $4: 1$, being 4 units in length of fiber fabric for each unit of cross-sectional area of the joint. This methodology was adopted after the execution of preliminary tests that used different fiber tissue lengths, in which the occurrence of shear ruptures in the fiber/wood bonding (for a smaller proportion) and ruptures in the base of the test specimen were observed (for a larger proportion).

Table 2 summarizes the experimental design adopted. A total of 221 tensile stranght parallel to the grain test specimens having as variables the geometries; the species and three reinforcements composition, being: (i) a layer of carbon fiber tissue, (ii) a layer of glass fiber tissue and (iii) two layers of glass fiber tissue. The control specimens were from bulk wood without joints.

Table 2. Experimental plan.

Tabela 2. Plano experimental.

\begin{tabular}{|c|c|c|c|}
\hline Species & Geometries & Reinforcements & $N$. of test specimen \\
\hline \multirow{9}{*}{ Pinus taeda } & \multirow{4}{*}{ A } & Glass & 10 \\
\hline & & Glass 2 & 10 \\
\hline & & Carbon & 10 \\
\hline & & Unreinforced & 10 \\
\hline & \multirow{4}{*}{ B } & Glass & 15 \\
\hline & & Glass 2 & 15 \\
\hline & & Carbon & 15 \\
\hline & & Unreinforced & 15 \\
\hline & Control & Without finger-joint & 10 \\
\hline \multirow{10}{*}{ Eucalyptus spp. } & \multirow{4}{*}{ A } & Glass & 10 \\
\hline & & Glass 2 & 10 \\
\hline & & Carbon & 10 \\
\hline & & Unreinforced & 10 \\
\hline & \multirow{4}{*}{ B } & Glass & 15 \\
\hline & & Glass 2 & 15 \\
\hline & & Carbon & 15 \\
\hline & & Unreinforced & 15 \\
\hline & Control Sample & Without finger-joint & 15 \\
\hline & Total & & 225 \\
\hline
\end{tabular}

Caption: N. = number; Glass = A layer of glass fiber fabric; Glass2 = Double layer of glass fiber fabric; Carbon = a layer of carbon fiber fabric; Unreinforcement $=$ With finger-joints and without reinforcement application; Without finger-joint $=$ test specimen in bulk wood.

\section{Technological evaluation tests}

The tensile strength parallel to the grain test was executed in Universal Testing Machine, model EMIC DL 30000, with increasing monotonic loading rate of $10 \mathrm{MPa} / \mathrm{min}$, in test specimens adapted of NBR 7190 (1997), because the norm does not describe an application model of reinforcements in finger-joints.

To test specimens for basic density and moisture content determination were taken from the tops of the tensile strength specimens (Figure 1). The procedures for obtaining bulk density and moisture content of the wood followed the NBR 7190 (1997) standard.

It was also performed the failure mode analysis of the specimens submetted to the tensile strength parallel to the grain test according to the AST D 4688 (1999) standard, which suggests six failure modes, based on the number of occurrence, identified as follows:

- Mode I = Rupture throughout the surfaces of glue line with few imperfections (rupture in the wood < $70 \%)$

- Mode II = Rupture throughout the surfaces of glue line with considerable shearing rupture (rupture in the wood $>70 \%$ );

- Mode III = Rupture throughout the finger-joint profile, but with some rupture in the base of the joint. Considerable shearing rupture in all profile surface;

- Mode IV = Rupture in the base of the finger-joints. Few imperfections throughout the profile;

- Mode V = Rupture that starts in the end of the finger-joint and continues in the wood;

- Mode VI = Rupture in the wood (not influenced for the finger-joint - all the rupture is in the wood). 


\section{Statistic Treatment}

Completly randomized design was used (CRD) in two distinct analyses, one for each species. In each one of the analyses the performance of the 8 treatments was evaluated: A Glass, A Glass 2, A Carbon, A Unreinforced, B Glass, B Glass 2, B Carbon, B Unreinforced, in relation to the control specimen (without fingerjoints) by Dunnett test at $95 \%$ reliability. The analyses were performed in the statistical software SAS ${ }^{\circledR}$ 9.4.

\section{RESULTS}

Tables 3 and 4 present the results of the analysis of variance (ANOVA) for the tensile strength parallel to the grain $\left(f_{t, O m}(12 \%)\right)$ of the species P. taeda e Eucalyptus spp., respectively. Both species evaluated presented significant differences according to ANOVA.

Table 3. ANOVA results for P. taeda.

Tabela 3. Resultados ANOVA para para P. taeda.

\begin{tabular}{lrrrrr}
\hline Source of Variation & Degrees of freedom & Sum of the squares & Average Square & Calculated $F$ & $P r>F$ \\
\hline Model & 8 & 15973,83 & 1996,73 & 15,18 & 0,0001 \\
Error & 78 & 10258,86 & 131,52 & & \\
Total corrected & 86 & 26232,70 & & & \\
\hline
\end{tabular}

Table 4. ANOVA results for Eucalypus spp.

Table 4. Resultados ANOVA para Eucalyptus spp.

\begin{tabular}{lrrrrr}
\hline Source of Variation & Degrees of Freedom & Sum of the Squares & Average Square & Calculated $\boldsymbol{F}$ & Pr $>\boldsymbol{F}$ \\
\hline Model & 8 & $4.412,17$ & 551,52 & 2,10 & 0,0402 \\
Error & 124 & $32.502,44$ & 262,12 & & \\
Total corrected & 132 & $36.914,61$ & & & \\
\hline
\end{tabular}

Figure 2 and 3 present, for each species, the results of mean comparison test, corrected at $12 \%$ of moisture content, of treatments with the respective control specimens (without finger-joints) in accordance with Dunnett test $(\alpha=0,05)$ and its standard deviation. The critical value of Dunnett test was of 2,69 for both analyses.

Figure 2. Dunnett test results for P. taeda.

Figura 2. Resultados do teste de Dunett para P. Taeda.

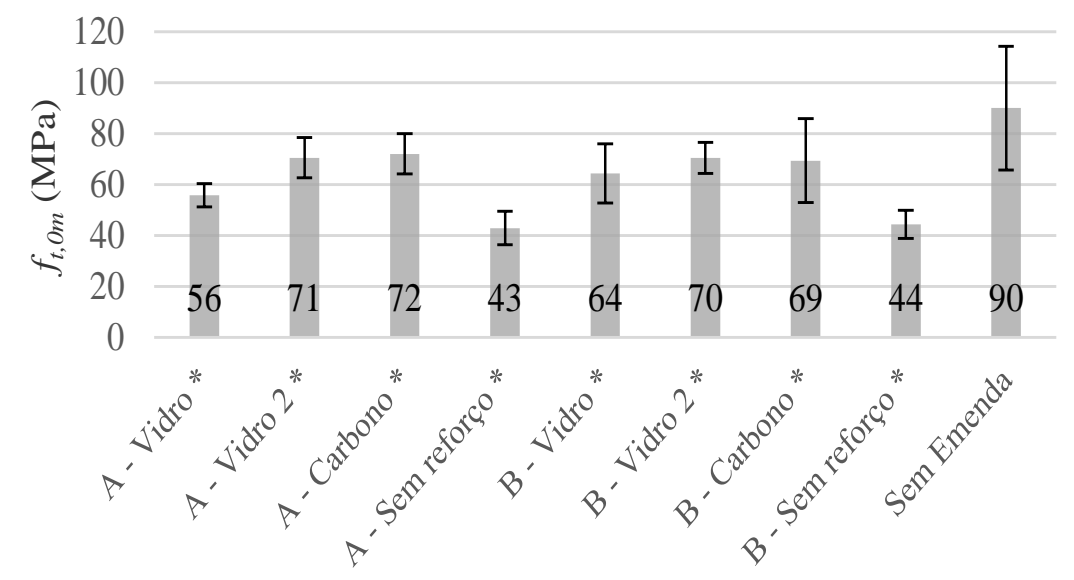

Caption: $f_{t, 0 m}=$ Mean tensile strength parallel to the grain; Glass = A layer of glass fiber fabric; Glass $2=$ Double glass fiber tissue layer; Carbon = a carbon fibre tissue layer; A and B = Geometries; $(*)$ Treatments followed by asterisk are significantly different from control sample (without emendation) by Dunnett test $(\alpha=0,05)$. 
Figure 3. Dunnett test results for Eucalyptus spp.

Figura 3. Resultados do test de Dunett para Eucalptus spp.

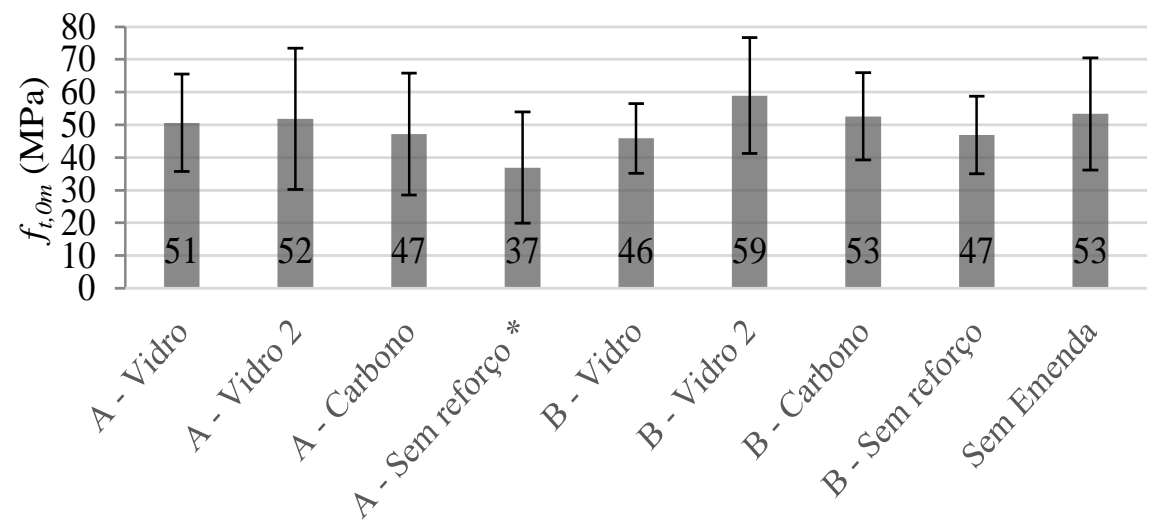

Legend: $f_{t, 0 m}=$ Mean tensile strength parallel to the grain; Glass = A layer of glass fiber fabric; Glass $2=$ Double glass fiber fabric layer; Carbon $=\mathrm{a}$ carbon fibre fabric layer; $\mathrm{A}$ and $\mathrm{B}=$ Geometries; $(*)$ Treatments followed by asterisk are significantly different from control specimens (without finger-joint) by Dunnett test $(\alpha=0,05)$.

Table 5 presents statistical variables of each treatment to both analysis effectuated.

Table 5. Statistical variables - P. taeda and Eucalyptus spp.

Tabela 5. Variáveis estatísticas - P. taeda and Eucalyptus spp.

\begin{tabular}{|c|c|c|c|c|c|}
\hline Species & Treatment & $\begin{array}{l}\text { Mean } f_{t, 0 m} 12 \% \\
(\text { MPa })\end{array}$ & $\begin{array}{l}\text { Standard Deviation } \\
(\mathrm{MPa})\end{array}$ & $\begin{array}{l}C V \\
(\%)\end{array}$ & Efficiency (\%) \\
\hline \multirow{9}{*}{ P. taeda } & A Glass & 55,83 & 4,54 & 8,14 & 62,0 \\
\hline & A Glass 2 & 70,52 & 7,91 & 11,22 & 78,3 \\
\hline & A Carbon & 72,05 & 7,92 & 10,99 & 80,0 \\
\hline & A Unreinforced & 42,95 & 6,60 & 15,38 & 47,7 \\
\hline & B Glass & 64,33 & 11,64 & 18,09 & 71,5 \\
\hline & B Glass 2 & 70,47 & 6,09 & 8,64 & 78,3 \\
\hline & B Carbon & 68,39 & 16,44 & 24,04 & 76,0 \\
\hline & B Unreinforced & 44,38 & 7,57 & 17,06 & 49,3 \\
\hline & Without finger-joint & 90,02 & 24,25 & 26,93 & 100,0 \\
\hline \multirow{9}{*}{ Eucalyptus } & A Glass & 50,59 & 14,88 & 29,41 & 94,9 \\
\hline & A Glass 2 & 51,81 & 21,64 & 41,77 & 97,2 \\
\hline & A Carbon & 47,16 & 18,63 & 39,50 & 88,4 \\
\hline & A Unreinforced & 36,89 & 17,02 & 46,14 & 69,2 \\
\hline & B Glass & 45,84 & 10,66 & 23,25 & 86,0 \\
\hline & B Glass 2 & 58,96 & 17,73 & 30,07 & 110,6 \\
\hline & B Carbon & 52,60 & 13,35 & 25,39 & 98,6 \\
\hline & B Unreinforced & 46,86 & 11,87 & 25,32 & 87,9 \\
\hline & Without finger-joint & 53,33 & 17,13 & 32,13 & 100,0 \\
\hline
\end{tabular}

The mean moisture content of P. taeda lumberlot was $15.9 \%$ and of Eucalyptus was $12.3 \%$. The apparent $\left(\rho_{\mathrm{ap}}\right)$ and basic $\left(\rho_{\text {bas }}\right)$ densities of the evaluated species were, respectively, $0,49 \mathrm{~g} . \mathrm{cm}^{-3}$ and $0,40 \mathrm{~g} . \mathrm{cm}^{-3}$ for P. taeda and of 0,60 g.cm ${ }^{-3}$ and $0,47 \mathrm{~g} .{ }^{\mathrm{cm}-3}$ for Eucalyptus spp.

Failure modes were classified in accordance with the recommendations of ASTM D4688 (1999), based on occurrences number and are presented in table 4. 
Table 4. Modes of Rupture

Tabela 4. Modos de ruptura.

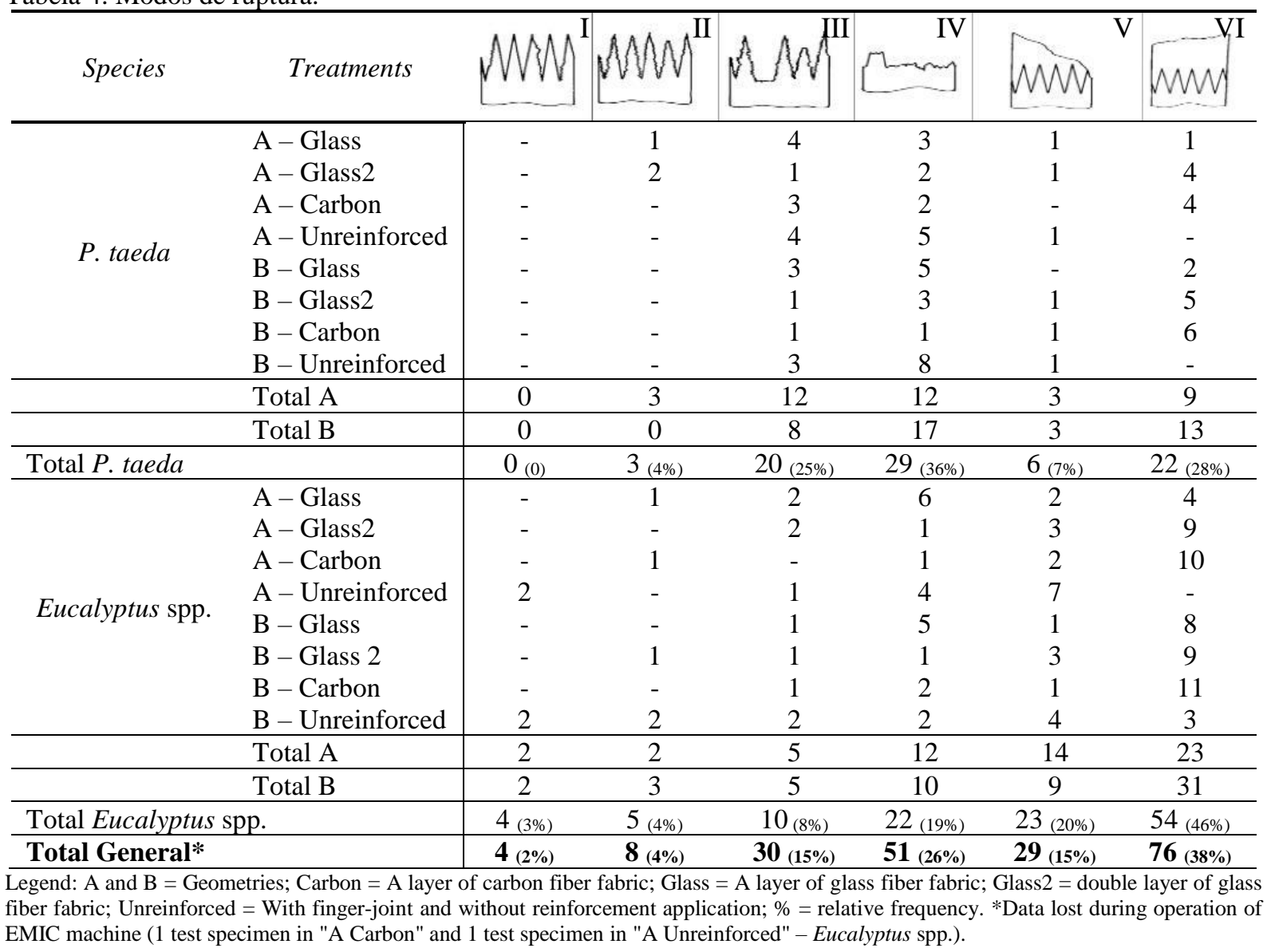

\section{DISCUSSION}

Tensile strangth parallel to the grains

The significant differences presented by the ANOVAs in the two performed analyses had been identified in function of the averages of the treatments by Dunnett test. The graphical results of Figure 2, referring to the species $P$. taeda, shows that all the evaluated treatments had been statistical inferior to the control specimens (without finger-joint). However, in relation to Figure 3, allusive to the species Eucalyptus spp., only the treatment "A - Unreinforced" presented statistically inferior average resistance to the control sample. Nevertheless, a combined analysis considering the standard deviations and coefficients of variation presented by the treatments (Table 5), bigger variability in the control specimens is observed comparing to the other treatments for the case of P. taeda, what does not occur with Eucalyptus spp., in which the evaluated treatments had similar behavior. High coefficients of variation within of the treatments, despite data homogeneity, can influence negatively in the performance of the mean comparison tests.

Raftery \& Harte (2013), studying the specie Irish-Grown Sitka Spruce, obtained maximum tensile strength parallel to the grain of $104 \mathrm{MPa}$ for test specimens without finger-joints and $45 \mathrm{MPa}$ for the specimens with finger-joints. This implies an efficiency loss of 56,7\% regarding the clear wood. Analyzing the results of Table 5, it is possible to verify that all the evaluated treatments, in both species, had presented lesser losses of resistance in relation to the presented one by Raftery \& Harte (2013).

Pereira et al. (2016), in study of unreinforced finger-joints with a hybrid of E. grandis Hill ex. Maiden with $E$. urophyla S. T. Blake, found out averages of $50.73 \mathrm{MPa}$ for test specimen without finger-joints and 19,10 $\mathrm{MPa}$ for test specimens with the finger-joint. The authors obtained a loss of efficiency of $62,4 \%$ in relation to the wood without emendations. Inferior performance compared to the unreinforced treatments evaluated in this study.

The determination of the weakness percentage does not consider directly the species and gluing pressure to be used in the finger-joints production. These factors can be related to the performance and are little 
explored by the PNBR (2011) or the Brazilian industries of GLULAM. The wood of Pinus taeda had loss of resistance of 52,3\% and 50,7\% for unreinforced geometries A and B, respectively. For Eucalyptus spp. the losses had been of $30,8 \%$ and $12,1 \%$, respectively. In this last case, geometry B had loss within the limits established by the degree of weakness estimated in Table 1.

Khelifa et al. (2015a) explain that finger-joints can reach approximately $85 \%$ to $90 \%$ of resistance of the wood without finger-joints, superior values to the results obtained in three of the four treatments $(P$. taeda "A Unreinforced", P. taeda "B Unreinforced" and Eucalyptus spp. "A Unreinforced") with unreinforced fingerjoints evaluated in this research, in which the geometries without reinforcement had inferior resistance to the degree of weakness esteemed (Table 1), although the main factors of influence has been controlled during the finger-joints execution. However, a gain in efficiency of the finger-joints for the treatments with reinforcement application is observed when compared with unreinforced finger-joints. Statistically, the results presented in Figure 3 shows that, for the Eucalyptus spp. the reinforce application with the same adhesive used by GLULAM industry is significantly more efficient, allowing to achieve performances similar to the clear wood.

\section{Physical properties}

According to Habipi \& Ajdinaj (2015), the GLULAM can be produced with wood of dicotyledons or conifers, which possess low density (inferior densities to $0,7 \mathrm{~g} / \mathrm{cm}^{3}$ ). Due to the fact that these ones present, generally, easiness in gluing when they present a moisture content between $10 \%$ and $18 \%$. The results found in this work are in compliance with the requirements of NBR 7190 (1997) and the literature.

\section{Failure Modes}

According to Habipi \& Ajdinaj (2015), parts joined by finger-joints and produced from species of lesser basic density tend to fail in the wood, whereas those of high basic density shatter in the joints, where the mechanical resistance of gluing line concentrate the axial tensions. Considering that the average apparent densities ( $\rho_{\mathrm{AP}}$ ) of P. taeda and of Eucalyptus spp. had been of 0,49 and $0,60 \mathrm{~g} / \mathrm{cm}^{3}$ (Figure 3), respectively, this effect could not be observed clearly in Table 4, possibly due to great variation of intraspecific densities.

Bustos et al. (2003), evaluating gluing pressures time of cure in finger-joints with wood of Picea mariana (P. Mill.) B. S. P., obtained $80 \%$ of the ruptures in modes III and IV, superior frequency to the obtained in this research (Table 4). The high frequencies of ruptures in mode IV and VI, for the treatments with reinforcement application, indicate an effective improvement in the performance of longitudinal in relation to unreinforced finger-joints. The factors as the adhesive grammage and gluing pressure had also been important for a rupture in the wood.

The sizing of the structures takes in consideration the parameters of resistance of the wood and not of the longitudinal joints. In this way, it is possible to observe that the performance of reinforced emendations is similar to the one of wood, ensuring more uniform and constant composition of elements in GLULAM.

\section{CONCLUSIONS}

Through the analysis performed in this study it can be concluded that:

- the use of fibers increases the strength of the finger-joints equating them to wood without finger-joints for Eucalyptus spp. In this way, there is a redistribution of the tensile stress out from joints region, provoking rupture in more fragile areas of the wood;

- The use of one or two layers were enough to increase the resistance of the wood of Pinus taeda in relation to the wood without finger-joints, what requires more detailed studies on the number of layers and mainly on the coverage area of gluing the reinforcements;

- PUR adhesive used in the manufacture of structural elements in GLULAM can also be employed in the production of synthetic fiber reinforcements in the area of longitudinal finger-joints;

- the species must be considered in the determination of the degree of weakening that the geometry can cause in the tensile strength parallel to the grain;

- in general, the sizing of the structures takes in consideration the parameters of resistance of the wood and not of the longitudinal joints. In such a way, it was possible to observe that the performance of the strengthened finger-joints for Eucalyptus spp. was similar to the one of the clear wood, what can assure more uniform and constant composition of elements in GLULAM, without mechanical resistence losses. 


\section{ACKNOWLEDGMENTS}

To FAPESC and CAPES for the concession of research grant for accomplishment of this work. To wood mill companies IRCAL Madeireira Ltda. e Righez Madeiras Ltda. for the donation of the raw material and availability of manufacture structure. To WL Madeiras who kindly assisted in the machining process.

\section{REFERENCES}

ASSOCIAÇÃO BRASILEIRA DE NORMAS TÉCNICAS. NBR - 7190: Projeto de estruturas de madeira. Rio de Janeiro: ABNT, 1997. 107p.

ASSOCIAÇÃO BRASILEIRA DE NORMAS TÉCNICAS. Projeto de Revisão NBR - 7190: Projeto de estruturas de madeira. Rio de Janeiro: ABNT, 2011. 50p.

AMERICAN SOCIETY FOR TESTING AND MATERIALS. D4688 - 99 (reapproved 2005) Standard specification for adhesives used for laminate joints in nonstructural lumber products. Pennsylvania, 2005. 10p.

BAYATKASHKOLI, A.; SHAMSIAN, M.; MANSOURFARD, M. The effect of number of joints on bending properties of laminated lumber made from poplar (Populus nigra). Forestry Studies in China, v. 14, n. 3, p. 246-250, 2012.

BUSTOS, C.; MOHAMMAD, M.; HERNÁNDEZ, R. E.; BEAUREGARD, R. Effects of curing time and end pressure on the tensile strength of finger-joined black spruce lumber. Forest Products Journal, v. 53, n. 11/12, p. 85, 2003.

EUROPEAN STANDARD. EN 385:2001. Finger jointed structural timber - Performance requirements and minimum production requirements. CEN, 2001. 20P.

FINK, G.; KOHLER, J. Probabilistic modeling of the tensile related material properties of timber boards and finger joint connections. European Journal of Wood and Wood Products, v. 73, n. 3, p. 335-346, 2015.

HABIPI, B.; AJDINAJ, D. Wood finger-joint strength as function of finger length and slope positioning of tips. International Journal or Engineering and Applied Sciences (IJEAS). Vol.2. 2015.

HABIPI, B.; ÇOTA, H.; KODRA, A. The effect of fingers tips position on tensile strength of finger joint connection. Journal of International Academic Research for Multidisciplinary. Vol. 4. Issue 1. 2016.

IWAKIRI S.; TRIANOSKI, R.; DA CUNHA, A. B.; PRATA, J. G.; HARA, M.; BILA, N. F.; LUIS, R. C. G.; DE ARAÚJO, R. D.; VILLAS BÔAS, B. T. Avaliação da resistência de juntas coladas da madeira de Eucalyptus benthamii com diferentes adesivos e faces de colagem. Scientia Forestalis, Piracicaba, v. 41, n. 99, p. 411-416, 2013.

KHELIFA, M.; CELZARD, A.; OUDJENE, M; RUELLE, J. Experimental and numerical analysis of CFRPstrengthened finger-jointed timber beams. International Journal of Adhesion and Adhesives, v. 68, p. 283297, 2016.

KHELIFA, M.; LAHOUAR, M. A.; CELZARD, A. Flexural strengthening of finger-jointed Spruce timber beams with CFRP. Journal of Adhesion Science and Technology, v. 29, n. 19, p. 2104-2116, $2015 \mathrm{a}$.

KHELIFA, M.; AUCHET, S.; MÉAUSOONE, P. J.; CELZARD, A. Finite element analysis of flexural strengthening of timber beams with Carbon Fibre-Reinforced Polymers. Engineering Structures, v. 101, p. 364-375, 2015b.

MOLINA, J. C.; CALIL NETO, C.; CHRISTOFORO, A. L. Tensile strength of finger joints made of Manilkara huberi wood for use in glued laminated timber. Ambiente Construído, v. 16, n. 1, p. 221-227, 2016.

PEREIRA, M. C. DE M.; CALIL NETO, C.; ICIMOTO, F. H.; CALIL JUNIOR, C. Evaluation of tensile strength of a Eucalyptus grandis and Eucalyptus urophyla hybrid in wood beams bonded together by means of finger-joints and polyurethane-based blue. Materials Research, v. 19, n. 6, p. 1270-1275, 2016.

RAFTERY, G. M.; HARTE, A. M. Nonlinear numerical modeling of FRP reinforced glued laminated timber. Composites Part B: Engineering, v. 52, p. 40-50, 2013.

RAO, S.; GONG, M.; CHUI, Y. H.; MOHAMMAD, M. Effect of geometric parameters of finger joint profile on ultimate tensile strength of single finger-joined boards. Wood and Fiber Science, v. 44, n. 3, p. 263-270, 2012. 
SEGUNDINHO, P. G. de A.; ZANGIÁCOMO, A. L.; CARREIRA, M. R.; DIAS, A. A.; LAHR, F. A. R. Evaluation of glued laminated timber beams of cedrinho (Erisma uncinatum Warm.). Cerne, v. 19, n. 3, p. 441449, 2013

STERLEY, M.; SERRANO, E.; ENQUIST, B.; HORNATOWSKA, J. Finger-jointing of freshly sawn norway spruce side boards - A comparative study of fracture properties of joints glued with phenol-resorcinol and onecomponent polyurethane adhesive. Materials and Joints in Timber Structures. Springer Netherlands, 2014. p. $325-339$ 